Planet or New Star?-The current number of Comptes rendus contains an announcement which astronomers would regard with much interest if it were substantiated. Dr. Lescarbault, the astronomer on whose statement the existence of the intra-Mercurial planet Vulcan mainly relies, observed a bright body in I.eo on January II, and, being unable to find it mapped in any atlas in his possession, he estimated its position as R.A. I $\mathrm{Ih} .4 \mathrm{~m}$., Decl. $6^{\circ}$, and concluded that the body was a new star, or one suddenly increased in brilliancy. There is little doubt, however, but that Dr. Lescarbault is mistaken in his conclusions, and that the body observed was the planet Saturn, whose position on the date named was R.A. IIh. $15 \mathrm{~m}$., Decl. $6^{\circ} 59^{\prime}$.

\section{THE FUTURE OF GEOLOGY.1}

I PURPOSE, in this my retiring address, to make some observations and offer some suggestions as to the future of geology. Not, indeed, that I can claim the rôle of a prophet. But there are indications in the tone and manner of recent dis cussions and research which point clearly to the probable course of geological investigations in the immediate future. Geology has lately become too speculative. For at least a second time in its history we need to pause in order to gather up the records of the past, and to think seriously about the best method of progress in the future. A century ago, the conflict between the Wernerian and Huttonian theories was at its height. Speculation upon imperfect data ruled all. The practical work of William Smith and other English geologists, and the common sense of Englishmen, stayed this mad theorizing ; and in the year 1807 the Geological Society of London was established for the express purpose of observing facts and recording observations. The results of this transference of energy from fierce controversy and dispute to patient investigation and labour of detail have been magnificent. And now again the old lines of controversy are reopened. The extraordinary revelations of recent microscopical research, and other improved modern methods, have necessarily reacted on physical geology; and there is once more great danger lest patient labour and accurate induction from proved data should give place to wild theorizing and acrimonious controversy.

The future of geology depends primarily on its practical uses. The method of its study, also, including the possible discovery of new methods of research, must be a potent factor in its development. Not less important is the consideration of the problems, whether physical, stratigraphical, or biological, which at present demand solution. And, as in all sciences and in all life, surrounding influences and environment have much to do with growth and progress. On each of these four points I wish to make a few remarks.

(r) The practical use of geology has received a striking illustration during the past year. Thirty-five years ago $\mathrm{Mr}$. Godwin-Austen maintained the probability of Coal-measures beneath the newer strata of the south-east of England; and such Coal-measures have now been found. To the civil engineer, to the miner, to the stone-mason, builder, and architect, to the well-sinker and searcher for water, a knowledge of geology has become essential ; and even so humble a person as the modern farmer and gardener might learn something from the coprolite and manure beds of the geologic series, and from the disposition of rocks and soils. During the past year nineteen committees appointed by the British Association have been concerned with geological subjects. Some of these are speculative and theoretic, but the majority are of practical use. The rate of increase of underground temperature has a direct bearing on mining operations; the circulation of underground waters is of great importance to the water-supply of towns and cities; the manure gravels of Wexford may revive the husbandry of Ireland; the flora of the Carboniferous rocks may throw light on the origin of coal and the probabilities of its occurrence in new localities; and even such apparently theoretic themes as the fossil Phyllopoda of the Palæozoic rocks, the Higher Eocene beds of the Isle of Wight, the erratic blocks sacred to our friends Dr. Crosskey and Mr. Martin, or the collection and identification of meteoric dust, may prove of importance in a practical direction. But not the least valuable are those researches which deal with foreign localities; and the Atlas Range of Morocco, the earthquakes of Japan, and volcanic phenomena of Vesuvius,

'Presidential Address by the Rev. G. Deane, D.Sc., delivered before the Birmingham Philosophical Society on October 8, 1890 .

NO. I IO9, VOL. 43] may vie in value with the Bridlington sea-beach, and the action of waves and currents on the beds and foreshores of estuaries. So long as British enterprise is forcing its way to the centre of Africa, and exploring the Australian continent and the larger islands of the East, a fuller knowledge of foreign geology becomes imperative.

But apart from these matters of general interest or worldwide importance, the practical use of geology is exemplified in the researches of individual observers, and of societies like our own. The investigations of Dr. Callaway in the Uriconian rocks. of Shropshire; the discovery by Dr. Lapworth of the Pre Cambrian rocks at the Lickey and Nuneaton; and the more recent discovery by Mr. Landon of the Lower Bunter Sandstone at Barr Beacon, considerably to the east of the South Staffordshire coal-field, which had hitherto been thought to be its limit, are all illustrations of what may still be done by patient and zealous work. The crown of future success rests on the brow of toil and thought. Even the things of theory and speculation ofttimes become exalted into practical service by the growing developments of advancing knowledge, and the varying demands of human progress.

(2) I advance now to the method in which geology should be studied, and the possible discovery of new means of research. The day has long gone by when geology could be viewed "as a fashionable toy that everyone who has been to school is supposed capable of handling." No one now dares to touch its problems without some knowledge of physics, mathematics, biology, and chemistry. When Dr. Buckland led his tribe of random riders amongst the Oolitic strata of Oxford, or when Sir Roderick Murchison discoursed in sapient language on the rocks of Siluria, geology might have been a "fashionable toy." But not so now. The stern requirements of modern days have made it more accurate, and rendered it more sure. And with its enlargement has come an attention to minute detail, an observance of processes and of the results of processes which in the olden days had no place. To be a geologist now, at all events in the special phases of the science, a man must be either a mathematician, a physicist, a master of biology or of chemistry. Happy the man who can combine the whole!

Prof. A. H. Green, of Oxford, in his recent address as President of the Geological Section of the British Association, at Leeds, discoursed on the value of geology as an educational instrument. He began by admitting candidly that geologists were in danger continually of becoming loose reasoners, because the data from which they reasoned were necessarily scrappy and the geological record imperfect, or the facts were capable of interpretation in more than one way, or the determinations were shrouded in mist and obscurity. Notwithstanding this, he urged that the study of geology would be useful educationally by teaching wariness when the pupil comes to handle the complex problems of morals, politics, and religion. Further :- "There are immense advantages," he continues, "which the science may claim as an educational instrument. In its power of cultivating keenness of eye it is unrivalled, for it demands both microscopic accuracy and comprehensive vision. Its calls upon the chastened imagination are no less urgent, for imagination alone is competent to devise a scheme which shall link together the mass of isolated observations which field work supplies ; and if, as often happens, the fertile brain devises several possible schemes, it is only when the imaginative faculty has been kept in check by logic that the one scheme that best fits each case will be selected for final adoption. But, above all, geolugy has its home, not in the laboratory or study, but sub fove, beneath the open sky, and its pursuit is inseparably bound up with a love of Nature, and the healthy tone which that love brings alike to body and mind" (Times report, September 5 ; NATURE, vol. xlii. p. 455). Prof. Green proceeds to argue that geology should be taught in schools for more prosaic reasons; the two chief of which are that geography, and especially physical geography, cannot be taught without constant reference to certain branches of geology, and that there are many points of contact between the history of nations, the distribution and migrations of peoples, and the geological structures of the lands which they have dwelt in or marched over. And he concludes by sundry good illustrations of such school teaching, into which I need not now follow him.

Many may be disposed to think that this able and admirable address of Prof. Green is overstrained and overstated. But it must be remembered that, in order to convince the British public, it is necessary to state things strongly, and to draw things 
clearly and deeply. I do not myself believe that the average school boy and school girl need to be taught "wariness" in matters of morals, politics, and religion. They are generally wary enough about these matters as it is; and, what is more, soon get weary of them. And, possibly, too much stress is laid upon the relation of geological structure to the history of nations and the migrations of peoples. An enthusiastic geologist might feel inclined to generalize that, inasmuch as the two great battles of the Franco-German war of 1870-Gravelotte and Sedan-were fought upon Jurassic strata, therefore such strata facilitate military operations, and all the great battles of history were fought upon Jurassic strata.

But, allowing that there may be some overstatement and special pleading, there is a great amount of truth in the address from which I have quoted. Many people go through life with their eyes shut. They do not really see what they think they see; and what they think they see is not what they ought to see-not what exists and presents itself to them. Whatever, then, trains to accurate observation of facts and phenomena is of value as an educational instrument. The great end of education is to call out and train the powers we possess, whether of mind or body. Whatever, therefore, develops and strengthens a faculty will further this end ; and that scheme of training which best fosters all the powers of mind will be the most satisfactory. The mathematician is apt to think lightly of the probable and moral reasoning of the philosopher, and the classic sometimes prone to scorn the pretensions of science. For the highest kind of education, a severe, long:continued, and isolated application to one special branch of study is requisite; though there is then great danger that the mind will become warped and one-sided. But, for the initial stages of education, the pursuit of a definite science will tend to supplement and complete the discipline of other studies, and to render the juvenile mind totus, teres, atque rotundus.

Prof. Green has done good service in urging the claims of geology in this direction. It can never take the place of physics or chemistry ; but it is at least the equal of either biology or physiology for training the mind to accurate and complete observation of facts and phenomena. The word has come from the chair of authority not a day too soon; and it is to be hoped that ensuing years may witness a great extension of geological teaching in our schools for both boys and girls.

The British Islands form the natural home of geological science. Though limited in area when compared with other countries, they contain in this small space a very great variety of different strata. Indeed, with one or two exceptions of no very great importance, the whole succession of geological rocks is represented in our land. Though we have not the immense development of one particular formation which occurs in some other regions, we have an immense variety of formations. The surface of our country is a miniature picture of the whole geological series ; and England, Wales, Scotland, and Ireland thus become the key to the world.

Accordingly, it is not surprising that, in Britain, geology has been an honoured science, and that its leading votarie have attained a world-wide reputation. Other lands have nobly borne their share in discovery and speculation; but I think we may justly claim for Britain the crown of geological progress As a science, geology began to emerge in Italy in the sixteenth and seventeenth centuries. Pythagoras, Strabo, and others of the ancients had, indeed, speculated on cosmogonies; but in Italy, at the time mentioned, the fossils of the sub-Apennine hills led to genuine geological controversy. A century later, Werner in Saxony, and Hutton in Edinburgh, were the great teachers of the science; and at the beginning of the presen century the formation of the Geological Society of London based the study of geology upon a rigid induction of facts, and tended to discountenance crude speculation and hasty theory. Since then the nations of Europe and America have striven in friendly rivalry to further the knowledge of the science they love so well

I am well aware that in two branches of study, as I shall explain further on, Britain until recently has lagged behind other countries. But this notwithstanding, Britain may well claim to be amongst the foremost in geological research. And we may to-night remember that Birmingham is the centre and apex of England, and that within a comparatively short distance from this room nearly all the geological formations can be observed and studied. Few places are more favourably situated for extensive and varied research than Birmingham. Within a distance of little more than fifty miles from this spot you may study the representatives of all the systems of rocks except the upper part of the Oolitic. the Cretaceous, and the Tertiary groups. And what are fifty miles in these days of railways? At slight expense and slight fatigue, a day's fresh air and bracing work full well repay the geologist. And within almost walking distance abundant materials for geologic study and pleasant recreation may be found. The Clent Hills, the Bromsgrove Lickey and the Severn Valley, the Clee Hills, the rocks of Ludlow, Wenlock, and South Derbyshire, the hills of Dudley and Rowley Regis, of Barr Beacon and Sedgley, of Coalbrook. dale and the Wrekin, of Church Stretton, Charnwood Forest, Malvern, and the Cotswolds, are all within easy reach. And these together represent almost the whole of the series of known rocks, whether igneous, sedimentary, or metamorphic.

I have claimed for Great Britain pre-eminence in geological research. I might also claim for Birmingham pre-eminence in one, if not in both, of the branches of geological study which Great Britain has until recently neglected. In the chemical constitution of rocks, and their microscopical structure, the Continental geologists have in years gone by done better work than the English. But we are in recent years striving to wipe away this reproach. Forty years ago Mr. Sorby, of Sheffield, commenced his microscopical researches; and, in Birmingham, Mr. Samuel Allport has been conspicuous for success in this line of investigation. Mr. Teall, of the Geological Survey, Prof. Bonney, and many others, have amply redeemed, in this respect, the credit of the country. At the present time Dr. Callaway, Mr. T. H. Waller, and others, are making large use of this method of inquiry.

The chemical relations of geological questions do not even now command in England the attention they deserve ; as there is a wide field of research for a qualified chemist in geological problems.

The study of a complex science like geology, then, includes almost all other sciences. In order to understand the real bearings of the manifold questions that emerge, the geologist needs to be almost omniscient. He must know something of almost every physical science-chemistry, mineralogy, and crystallography; what is now known by the name of physiography, including meteorology and natural philosophy; biology, physiology, and anatomy are all requisite. Microscopical research is essential. And if the higher parts of mathematics can be added, the observer will be still better equipped.

The past year has seen a new direction of enterprise in regard to the registration of geologic facts. The photographic art has been called into organized recognition. At the meeting of the British Association held at Newcastle-on-Tyne in September I889, a committee was formed to arrange for the collection, preservation, and systematic registration of photographs of geological interest in the United Kingdom. In some counties, as in our own, this impetus has taken a rather wider sweep, and aims at a general photographic survey of the county. As is known to many here present, an influential county council has been appointed for this purpose in Warwickshire, with Mr. J. B. Stone as president, and Mr. W. J. Harrison as secretary; and two members of this Society have been delegated to act thereon. Unquestionably many instructive geological sections have been lost to science through want of correct drawing, or photographing, at the time of their exposure ; and it is hoped that this committee may aid in recording and retaining such facts. The result of the first year's work has been satisfactory; and the report to the Association at the Leeds meeting shows that 196 geological photographs have been sent in. It is to be hoped that in years to come this method of rendering permanent transient sections may be productive of good.

The possible discovery of new methods of research opens up a wide field of speculation, into which time forbids me to enter at large. Improvements made in modern optical instruments have enabled the geologist to see through a brick wall, or force his way through a prickly problem; and the day may not be far distant when the very centre of the earth will be as clearly seen and understood as its surface now is. One of the most promising new methods of research is the separation of minerals by means of heavy solutions, and other methods are sure to come. It remains to be seen how far the recent marvellous advances in electrical science may throw light on the problems of rock metamorphism. The transitions from one kind of rock into another are startling and puzzling; and it may possibly be found that terrestrial magnetism and electrical force are potent factor in the results which field geologists have observed and recorded.

NO. I IO9, VOL. 43] 
The genius of discovery is not yet exhausted; and the triumphs of the last fifty years augur an enlargement and expansion in the immediate future which will place the science of geology in the forefront of human progress.

(3) Passing now to the problems, whether physical, stratigraphical, or biological, which at present demand solution, I may remark that an ex-President of this Society-Mr. William Mathews - in the year 1883, made this topic, with great lucidity and power of reasoning, the theme of his address. Mr. Mathews dealt with four subjects : the doctrine of uniformity, the origin of mountains, the supposed cause of glacial epochs, and the eroding power of ice. As I have myself, in various papers read either before this Society or before the Natural History and Microscopical Society, discussed more or less fully the whole of these subjects, I do not propose touching them to-night. In fact, the last seven years have brought other questions to the front, on which I may venture to dilate.

Prof. Huxley, in his address as President of the Geological Society of London, in the year I 869 , traced three phases of geological speculation, viz. the catastrophism of Murchison and the older geologists, the uniformitarianism of Hutton, Playfair, and Lyell, and what he styled evolutionism, which adopts all that is sound and good in the other two, and is destined to swallow them up. He argued that both catastrophism and uniformitarianism had kept alive the tradition of precious truths: catastrophism in insisting upon the existence of a practically unlimited bank of force, on which the theorist might draw ; and uniformitarianism in insisting on a practically unlimited bank of time, ready to discount any quantity of hypothetical paper. And he maintained that there is no sort of theoretical antagonism between the two, as it is very conceivable that catastrophes may be part and parcel of uniformity; and still less is there any necessary antagonism between either of these doctrines and that of evolution, which embraces all that is sound in both, and applies the same method to the living and not-living world.

I consider the position thus taken up by Prof. Huxley to be absolutely impregnable. It is well to bear in mind that geology knows at present no finality. Time-honoured views have been shattered and pulverized by the recently-published papers on the Highlands of Scotland, and by both Continental and English geologists on the structure of the Alps. And no one could have attended the London meeting of the Congrès Géologique International without seeing that grave changes in geological conceptions, and in geological interpretations, are impending. The school of evolution will indubitably swallow up those of catastrophism and uniformitarianism.

And if evolution thus bids fair to dominate physical and stratigraphical geology, its influence can also be traced in the succession of living forms. Prof. Huxley himself has done as much as any living man in this direction. In his well-known lecture before the Royal Institution on February 7, r868, he conclusively showed that bird fossils are reptilian in their character, and the reptile fossils of the Secondary rocks are birdlike in character. And further, in his lectures at the Royal School of Mines, in 1876 , he gave a long and exhaustive series of transitional links, from the Ceratodus of the Trias, which affords a connecting link between fish and Amphibia through the reptilian types of the Secondary rocks, to the protohippus, hipparion, anchitherium, palæotherium, and orohippus of the Tertiary rocks, which are links of transition from the modern horse to the rhinoceros, the pigs, and the ruminants.

The recapitulation theory of development, as expounded in the writings of Fritz Muiller, von Baer, Balfour, and Haeckel, supports the theory of evolution; and has been explained and illustrated at great length and with much power by Prof. A. Milnes Marshall in his recent brilliant address to the Biology Section of the British Association at Leeds. He writes :-

"The doctrine of descent, or of evolution, teaches us that as individual animals arise, not spontaneously, but by direct descent from pre-existing animals, so also is it with species, with families, and with larger groups of animals, and so also has it been for all time; that as animals of succeeding generations are related together, so aiso are those of successive geologic periods; that all animals living or that have lived are united together by blood relationship of varying nearness or remoteness; and that every animal now in existence has a pedigree stretching back, not merely for ten or a hundred generations, but through all geologic time since the dawn of life on this globe.

NO. I IO9, VOL. 43]
" The study of development, in its turn, has revealed to us that each animal bears the mark of its ancestry, and is compelled to discover its parentage in its own development; that the phases through which an animal passes in its progress from the egg to the adult are no accidental freaks, no mere matters of developmental convenience, but represent more or less closely, in more or less modified manner, the successive ancestral stages through which the present condition has been acquired.

" Evolution tells us that each animal has had a pedigree in the past. Embryology reveals to us this ancestry, because every animal in its own development repeats this history, climbs up its own genealogical tree" (NATURE, vol. xlii. p. 468$)$.

The theory of evolution, then, in some one or other of its forms, must be accepted as the basis of the geology of the future. The physical problems which in past years have been examined and discussed by Sir William Thomson, M. Delauney, the Rev. Osmond Fisher, and others, have in recent years been still further elucidated; conspicuously so by our excellent secretary, Mr. Davison, and Mr. T. Mellard Reade. The stratigraphical problems have called in the aid of thrust planes, reversed faults, dynamo-metamorphism, and catastrophes to alter the dead level of uniformity. And the biological problems are explicable only on some theory of evolution. In Huxley's words, evolution is destined to swallow up the other two theories.

Perhaps the most striking development of modern geology is the rise and growth of the Congrès Géologique International; and the questions discussed thereat are, of course, the prominent questions of the present time. Beginning its existence at Paris in 1878 , it has since met at Bologna in 1881 , Berlin 1885 , London I888, and the next meeting is fixed for Philadelphia in 1891. Its growing importance is indicated by the numbers of foreign members in attendance. These were:-Paris IIO, Bologna 75, Berlin 92, London I5 1 , and our American cousins next year, as is their wont, will probably "whip creation." As I had the pleasure of attending the London meetings, I read a paper thereon before the Geological Section of this Society, and allude to the subject now only because the topics of the Congress suggest the matters which are under immediate discussion. These were three-the map of Europe, nomenclature and classification, and the nature and origin of the crystalline schists.

The geological map of Europe is under the care of an influential committee, meeting in Berlin, on which Germany, France, Great Britain, Austria-Hungary, Italy, Russia, and Switzerland, are all represented. The scale adopted is I : I, 500,000; that is, I inch to 23.673 miles; and the map will consist of forty-nine sheets. Some parts of Central Europe are on the eve of publication; and, although the colours are somewhat different from those we are accustomed to in England, it will be a great advantage to have uniformity of colouring for all European countries.

On nomenclature and classification, the Congress, having at the previous meetings dealt with the unification of geological terms, gave attention to the classification of the Quaternary and the Cambrian and Silurian strata. It was generally felt that, notwithstanding the insignificant thickness of the Quaternary strata, the advent of man and the existing mammals was suffcient to render this epoch rabsolutely distinct from the Tertiary. But on the great Cambro-Silurian question a battle royal ensued. As I have treated this fully in my previous paper, I must not take up time to-night upon it. This controversy still rages, both at the Geological Society of London, and in the pages of the Geological Magazine. Prof. Blake is mad on his Monian system; Dr. Hicks is naturally jealous for his Dimetian, Arvonian, and Pebidian of the St. David's promontory; Dr. Callaway is equally sensitive as to his Uriconian rocks of Shropshire; Dr. Lapworth, the inventor of the term Ordovician for the Upper Cambrian of Sedgwick and its equivalent the Lower Silurian of Murchison, may yet have something more to say before the controversy closes; and some of the Continental and American geologists seem to think the whole thing a storm in a teapot, and appear disposed to adhere to the ancient lines.

Closely connected with this controversy as to the base of the sedimentary rocks, comes the discussion concerning the nature and origin of the crystalline schists, which occupied two morning sittings at the Congress. Here, again, modern researches tend to subvert the older theories. Dynamic metamorphism, accompanied by recrystallization on freshly induced planes, curves, and surfaces, is now held to explain the most extraordinary 
transitions from one kind of rock into another. Both chemical analysis, aided by new methods, and microscopical investigation, with improved instruments, establish this conclusion; and it would seem likely that the immediate future would realize the reasoning of Hutton and Playfair that the sedimentary rocks give no indication of a beginning and no prospect of an end. Certain it is that the indications of bedding and sedimentary origin are encroaching fast upon what was only a short time ago considered part of the primæval crust of the earth. Some cases of supposed bedding, as for example in the Malvern crystalline axis and in some districts around the Wrekin, have been shown to be connected with igneous rock probably rearranged under great pressure. But as to the origin of the crystalline schists, Profs. Heim, of Zurich, Lehman, of Kiel, Drs. Lapworth and Callaway among ourselves, Dr. Hicks, and many other most able investigators, are firmly convinced that mechanical pressures and deformations are in reality the cause of the most sensational changes from both sedimentary and igneous rocks into crystalline schists. No doubt the old conflict will come on again, and it will be many years before these views will be universally accepted. But that they are destined to dominate the immediate future is as clear to me as the shining of the sun on a bright day at noon. The molecular changes induced by vast pressure and its accompanying natural forces are quite sufficient to change the structure and nature of crystals and rocks. Investigations in the field and in the laboratory will soon set these points at rest, though for some years to come the conflict of opinion may be strong and fierce. The chief difficulty at present is the apparent elimination of altumina and magnesia ; but I have little doubt our chemists of the future will solve this problem, and their researches will throw light upon the nature of these widely extended though little-known substances. When practical geologists speak of the crystalline schists and associated strata as "a jumble of rocks," it is time someone arose to reduce the "jumble" to order; and there is every reason to believe that chemical and microscopical research will speedily bring him.

(4) The last element in the future of geology which I propose to speak of may be expressed as the external infliences which bear upon the development of the science; so to speak, its environment.

Looking around at present upon geological activities in Britain, we find the Geological Society of London, the organization represented by the Geological Survey, a number of Societies scattered through the Kingdom which are devoted, either solely or partially, to the furtherance of geological research, and a large number of earnest individual workers in almost every nook and corner of the land. To these must be added the Royal Society, the Professors of the Science Colleges, with the great influence they spread, the British Association for the Advancement of Science, and the influence of the Universities in geological directions. With this vast army of workers geology must advance. Bnt, as in the past so in the future, it will be an advance amongst difficulties, and in the face of opposition and obstruction.

The spirit of the age has a mighty power on all things ; and it might be thought, at first sight, that the spirit of the age would urge the science of geology forwards at almost headlong speed. But I am not at all so sure of this: it may urge general scientific inquiry forwards, but the popular directions do not run on geological lines so much as on some others. To put the matter in a nutshell, geology does not pay; and it must be made to pay, before competent and trained men will be able to give time and toil to its pursuit. Very few competent persons can afford to give up their leisure, and also their money, from a mere love of the science.

The last twenty years have witnessed a great expansion in scientific matters. Science Colleges have been established in many of the great centres of population, and to most of these a Professor of Geology is attached; in the Board Schools of most large towns and cities, science is taught, and with it Geology to a greater or less extent ; more often less, and sometimes meagre. Private schools and organizations, likewise, sometimes favour, generally tolerate, the study. But still we are not happy. These things are not as they should be. Geology may reasonably claim a prominence it has not yet received.

In the days of Sedgwick, Buckland, Chalmers, Hugh Miller, Lyell, and Murchison, the leading geologists might be counted on your fingers; now they may be counted by scores, and it may confidently be expected that, notwithstanding pecuniary disability and in defiance of difficulties, the numbers will still increase. But at present the superior advantages of other lines of scientific thought and effort draw many away from the geologic path. Those who remain are attracted more by love of truth than hope of pay. If the amount of money sunk and lost through want of correct and accurate geological knowledge could be fully estimated, its total would be astounding. Some well-laid schemes, under good geological direction, doubtless have failed; but such are very few. The successes have greatly exceeded the failures. Here, close to Birmingham, the Sandwell Park Colliery may be pointed to ; and the "Search for Coal" Committee in the south-east of England, will, in all probability, render a good account of their labours. With such examples before us, the public zeal for geology ought to be greatly stimulated.

In estimating the spirit of the age with regard to geology, one element ought to be noticed, which I rather shrink from introducing here-I mean the past theological hostility to the science. I will, however, deal with it generally, without introducing controversial matters. This hostility is scotched, but not killed, as it ought to be by this time. In centres of intelligence it has now but little or no power, but it lingers in the dark places of the land. A perverted theological bias has never yet succeeded in preventing the ultimate advance of a correct and accurate science; but it may hinder and obstruct. Lukewarm friends are little better than open enemies; and unconscious influence, from the cause referred to, may, and probably does, hold back many from hearty and earnest support of geological work. What is wanted for genuine and full growth and progress is the earnest and sympathetic aid of all classes and conditions. If this be withheld, the growth will languish and the progress will lag. Compared with the past, indeed, we have reason for immense thankfulness; but the evil still lurks, and has yet to be faced and finally destroyed.

And now, to apply this spirit of the age to concrete existence, and attempt to read the future in the light of the present, that future will depend upon at least two main supports, viz. (r) the union and the rivalry of effort, and (2) the devotion of either public or private money to geological objects, and to the determination of crucial points.

(r) The union of effort is represented by the many Societies already referred to scattered over the face of the country; by the central bonds of the Geological Society of London and Section C of the British Association; and by the newly developing Congrès Géologique International, which promises good service in the common cause. Some of these Societies-Field Clubs especially - are more of the picnic and social character than is likely to conduce to effective progress of scientific research; and even the meetings of the British Association are open to some criticism on this score. In our Midland district, in 1876 , a new departure was started in the Midland Union of Natural History Societies; and this, after some vicissitudes, is still living a vigorous life; held a highly successful annual meeting at Oxford last yenr; and this year, at Leicester, a most pleasant meeting has been held, accompanied by two wellplanned excursions - one botanical, and the other geologicalthrough Charnwood Forest.

For one, I am not disposed to value lightly the influence of even mere social gatherings connected nominally with science. They tend to give a tone both to the neighbourhood where they are held, and to those who attend them; and also put people on the alert for possible discoveries. The experts in geology are few, but the watchers and labourers are many; and these last, scattered as they are throughout the country, may hear of or find put facts and points of interest which the experts may subsequently be called upon to examine and explain. Many an interesting geological fact, or even crucial section, has been lost simply because no one who understood the matter was at hand to decipher and preserve it, or report it to those who could do so. By all means let us increase our army of observers; what they hear of and discover experts can explain. A striking illustration of this kind of labour has recently occurred in this district. Mr. Sherwood, of Sutton Coldfield, found a freshly opened section near Barr Beacon, which exposed rocks that were new to him. He reported the fact to Mr. Landon, of Saltley College, who discovered an eroded surface of the Lower Bunter Sandstone, in a locality where it had previously been believed to be absent. Mr. Landon has since discovered quartzite implements in a river gravel at Saltley. I have had, in my own

NO. I IO9, VOL. 43] 
experience, similar illustrations, one of which is worth recording. When residing in the valley of the Ouse, in Bedfordshire, during an occasional absence from home, a well was sunk near my house. The workmen came upon the lower jaw of a hippopotamus, and of course proceeded to demolish it with their pickaxes. A friend of mine happened to pass, and he succeeded in saving for me some fragments of teeth and jaw. When I returned, the bulk of the remains had been used as stuffing to the back of the well. But my friend had saved sufficient to prove the existence of Hippopotamus major in that locality.

This union of effort necessarily involves some amount of friendly rivalry. It seems to be a law of humanity that two vigorous persons, jogging side by side along the same road, stimulate each other to increased pace. And so, in each society, the blending of effort is a stimulus to each individual worker. In a union of societies, the same power should be felt ; each will vie with the others, not simply for pre-eminence of course, but for progress. And the result comes unconsciously in the advancement of the object they have in common. Geologists in the nations of Europe and America, organized in various societies, and surrounded by different influences, have one common object, and mutually stimulate each other towards the attainment of full and complete geological knowledge. It may be, sometimes, that this rivalry will lead to strenuous conflict ; but conflict of opinion and thought, so long as personal rancour and strife are excluded, will always lead onwards in the path of truth.

(2) In approaching the matter of money-whether public or private-devoted to 'geological objects, I touch a subject of some magnitude, complexity, and difficulty. When the British purse is appealed to, buttons are often in requisition, not in liev of coins, but to close the exit of coins. But it is perfectly clear that geological investigation is expensive, and the pecuniary resources of most competent geological observers are limited. Geologists have to rely, for the most part, upon natural sections and exposures, or upon those artificial sections and borings which commercial enterprise opens up. A judicious expenditure of money to make artificial sections and borings, in order to determine crucial points, would often be amply repaid.

In the allocation of public money to geological objects, we have conspicuously before us the Geological Survey of the Kingdom, the maintenance of the Royal School of Mines, and the Natural History Museum at Kensington. Then, during the last year, a grant in aid of provincial Science Colleges has, after much agitation, been wrung from the Treasury; though how much of this will find its way to geological objects is very problematic. Perhaps the most significant "sign of the times" in this direction is the Report of the Committee, appointed by the Commissioners of the $185 \mathrm{I}$ Exhibition, as to the establishment of Science Scholarships in provincial and colonial Universities and Colleges. The second item of the Committee's recommendation runs thus: "That the scholarships be limited to those branches of science (such as physics, mechanics, and chemistry) the extension of which is specially important for our national industries" (NATURE, vol. xlii. p. 43I). Of course this is a case of complete powerlessness on the part of geologists. The Commissioners are acting within their rights, and after due deliberation. But, with all deference to the illustrious men of science who have drawn up this Report, I humbly think that geology ought not to be excluded from the subjects that are specially important for our national industries.

Various scientific Societies allocate money in aid of geological research. The grants from the Royal Society and the British Association have been of great service, not only in rousing activity, but also in rewarding, or rather recompensing, worthy work. The Geological Society of London has at its disposal several most honourable awards for well-spent labour. The medals come first-the Wollaston, Murchison, Bigsby, and Lyell Medals being the highest geological honours of the country. But the surpluses of these funds, as also the "BarlowJameson Fund," are allocated from time to time to repay in some measure the expenses of those who have rendered distinguished service and wrought good work. With us in the Midlands the Darwin Medal of the Midland Union, and the grants made from our " Endowment of Research Fund," are a humble reflex of such awards. There is ample scope for extension and enlargement in awards of this kind.

But perhaps the development of future British geology may come from other sources. The enterprise of the South-Eastern Railway directors has opened up the possibility of coal-fields where thirty-five years ago geologists said they might exist; and public companies can do much to aid further research. Private enterprise also may do much. This old land of ours is not yet used up, and one need not despair of discovering still, in its soil and rocks, fresh elements of permanence and power.

I have thus endeavoured to trace what seem to me to be the possibilities of future geology. There may be regions yet unsearched which will yield up their treasures to the diligent. The current controversies on theoretical points afford scope for the acutest intellect to unravel and explain. New methods of research give promise of coming discoveries. The spirit of the age and the surroundings of the science are favourable on the whole to progress. If money be forthcoming to meet needful expenses, and cbservers are careful and accurate, the past triumphs of geology will appear small compared to the triumphs that are yet to come.

\section{THE SOUTH AFRICAN DOCTRINE OF SOULS.}

$\mathrm{IN}$ the second of two interesting papers on the manners, cus-

toms, superstitions, and religions of South African tribes (Journal of the Anthropological Institute, vol. xix. No. 3, and vol. xx. No. 2), the Rev. James Macdonald, who has had ample opportunities of studying the subject, has a good deal to say about the doctrine of souls which prevails among the aborigines of South Africa. It is extremely difficult, he explains, to discover what the people really believe about the spirit world, so many and varied are the traditions relating to it. There are, however, certain outstanding facts common to all ; and of these Mr. Macdonald gives a clear and instructive account.

All human beings are supposed to have souls, but their souls are not believed to be entirely confined to the body. A man's soul may, it is thought, occupy the roof of his hut, and, if he changes his residence, his soul does so at the same time. Mr. Macdonald takes this to be a loose and indefinite way of expressing "the belief that a man's spirit may have in fluence at a distance from the place where he is himself at any time." The people often use the word "zitunzela"-from "izitunzi," shadows-to express their ideas of human spirits and the unseen world generally ; and this is " the nearest description that can be obtained." A man is constantly attended by the shadows or spirits of his ancestors as well as his own, but the spirit of one who dies without speaking to his children shortly before death never visits his descendants except for purposes of evil. In such cases magicians or priests offer costly sacrifices to prevent misfortune and death.

Great importance is attached to dreams or visions, which are supposed to be due to spirit influence. When the same dream comes more than once, the dreamer consults the magicians, who profess to receive revelations through dreams. If the dreamer has seen "a departed relative," the magician says, " $\mathrm{He}$ is hungry." Then a beast is killed ; the blood is collected, and placed in a vessel at the side of the hut farthest from the door the liver is hung up in the hut, and must not be eaten until al the flesh of the animal has been used. The "essence" of the food is "withdrawn" by the spirit during the night, and after a specified time ail may be eaten except the portions which the magician orders to be burned.

Ancestor-worship is not only professed by the South African tribes, but "they actually regulate their conduct by it." Says Mr. Macdonald :-

"If a man has a narrow escape from accident and death, he says, 'My father's soul saved me,' and he offers a sacrifice of thanksgiving accordingly. In cases of sickness, propitiatory sacrifices are offered to remove the displeasure of the ancestors, and secure a return of their favour. Should anyone neglect a national custom in the conduct of his affairs, he must offer sacrifice to avert calamity as the consequence of his neglect. When offering propitiatory sacrifices, the form of prayer used by the priest is: "Ye who are above, accept our offering and remove our trouble.' In freewill offerings, as in escape from danger, or at the ripening of crops, the prayer takes the following form : 'Ye who are above, accept the food we have provided for you; smell our offering now burning, and grant us prosperity and peace.'"

Animals are not supposed to have souls; neither are inanimate objects. But spirits may reside in inanimate objects, and their presence has an influence on many customs and babits. A striking example of such influence was afforded during the rebellion of 1879 , when Umhlonhlo, after the murder of the British Resident, was one day marching in a leisurely manner 